\title{
Democracy and Terrorism in Nigeria: An Empirical Assessment
}

\author{
Victoria Hauwa Ibrahim \\ Department of Government \\ University of Essex \\ Essex, United Kingdom.
}

\begin{abstract}
This study empirically investigates both the political and socio-economic determinants of terrorism in Nigeria by conducting a series of negative binomial regressions over the time period of 1999-2013. The study analyzed first the effect of a range of political variables like democratic participation, political competition and institutional constrains on the counts of terrorist incidents. Then the study probes the effect of the socioeconomic variables: GDP per capita, economic growth, and trade openness. The study lends credence to the hypotheses that greater democratic participation, political competition, and executive constraints increase the counts of terrorist events in Nigeria. Moreover, the study finds no strong empirical evidence to suggest that economic development reduces terrorism in Nigeria. The results show that modernization pressures and changing economic conditions has a small and significantly negative effect on terrorist incidents, Furthermore, contrary to the terrorism empirical literature, the results display that trade openness has a significant and positive relationship with terrorism in Nigeria, albeit a small one. The robustness checks, deploying an alternative dependent terrorist variable and a nationwide security poll carried out by NOIPolls to gauge the perception of Nigerians on the major causes of terrorism, yield very similar sets of results. The overall pattern of relationships remains essentially identical.
\end{abstract}

Keywords: Global Terrorism Database, Democratic Participation, Economic Development, Terrorist Incidents, Negative Binomial Regression Model, Boko Haram.

\section{Introduction}

Since Nigeria returned to democratic rulein 1999, the fledgling democracy has witnessed increased number of terrorist attacks on its soil. Nigeria has a long history of ethno-religious violence and terrorism. For instance, in the 1980's the puritanic Islamic fundamentalist sect called Maitatsine under the leadership of AlhajiMarwaMaitatsine evolved into a religious movement in Northern Nigeria that led to uprisings in Kano (twice in 1980). The uprisings later spread to Yola in 1982 and Maiduguri in 1983 (Oyovbaire, 1980 and Ajayi, 2012). Another remarkable terrorist event occurred in 1965 when a militant group from Southern Nigeria called the Niger Delta Volunteer Force (NDVF) under the leadership of Isaac AdakaBoro carried out a well-planned and coordinated terrorist attack that lead to loss of lives (civilian and military) and properties in the oil rich city of Port Harcourt (Stephen, 2009).

Despite the historical precedentsof terrorism in Nigeria, the government did not consider terrorism to be a major public policy thrust until the emergence of two 'home-grown' Islamic terrorist groups: Boko Haram and Ansaru. Boko Haram is known as Jama'atAhlas-Sunnah lid-da'wawal-Jihad, although it is most recognizable as Boko Haram (BH) in Nigeria and abroad, whereas the latter group called Ansaru (Jamā' atuAnşārilMuslimīnafīBilādisSūdān) is a splinter faction from the wider BH terrorist organization.

\subsection{Research Objectives and Hypotheses}

The main objective of this study is to examine the relationship between terrorism on the one hand, and democratic openness (i.e. political freedom and civil liberty) and socio-economic development in Nigeria, on the other. Terrorist incidents are measured by the total counts of terrorist attacks in Nigeria from 1970 to 2012. The source of the data is Global Terrorism Database (GTD). The political determinates of democratic openness, executive constraints, and regime durability and maturity are measured by the Freedom House Index: Sum of the political rights and civil liberty, while the primary socio-economic correlates: Gross Domestic Product (GDP) per capita, trade openness, and economic growth, are gleaned from the World Bank Dataset.

To achieve our research objective and evaluate the theoretical propositions, the study empirically tests five hypotheses. The first hypothesis states that greater democratic reduces the number of terrorist incidents in Nigeria. The second hypothesis posits that political competition increases terrorist incidents in Nigeria. 
The third hypothesis conjectures that institutional constraints on the executive increases terrorist incidents in Nigeria, whereas the fourth hypothesis states that higher economic development reduces terrorist incidents in Nigeria. The study's last hypothesis postulates that high prevalence of unemployment is a root cause of terrorism in Nigeria.

This research contributes to the literature on terrorism in two distinct ways. First, it fills the gap of empirical countrylevel evidence on the factors that influence terrorism in Nigeria, which has been hitherto, under researched. Last, the study offers opinion on the conflicting evidence in extant terrorism literature on the Bush Doctrine from a Nigerian standpoint.

\subsection{Motivation and Justification of Study}

This study is motivated by two factors. First, the lack of a country-level empirical study that examines the relationship between democracy and terrorism in Nigeria and the non-availability of hard empirical evidence on the determinants of terrorism that can predict the occurrence of terrorist incidents in Nigeria.

Further, the study is justified along two main lines. First, the study is very timely and relevant to public policy debate on terrorism in Nigeria, and second, the study will give a direction to counter-terrorism efforts by the Nigerian government.

\section{Literature Review}

\subsection{Political Economy and Demographics of Nigeria}

The Federal Republic of Nigeria comprises six geopolitical zonesand is made up of 36 states and a Federal Capital Territory (FCT). The states are further divided into 774 local government areas with over 250 ethno-linguistic groups. Despite the plurality of ethnic groups, Nigeria has mainly three major ethnic groups: Yoruba, Ibo and Hausa. Terrorist attacks are predominant in the Hausa dominated areas situated in the Northern part of Nigeria. Although terrorist attacks are rampant in Northern Nigeria, the North-East geopolitical zone which comprises Borno, Yobe, Taraba, Adamawa, Bauchi and Gombe states are the worst hit.

The most recent demographic estimates from the Population Reference Bureau (PRB, 2012) provides a mid-year population of 170.1 million for Nigeria, with 44 per cent of the population aged 0-14, 53 per cent of working age (1564), and 3 per cent over the age of 64. A disaggregation of the working age population shows that the youth population constitutes 19 per cent of the entire Nigerian population, while 25-54 and 55-64 age categories constitute 30 and 4 per cent of the population respectively.

According to the Nigeria Bureau of Statistics (NBS, 2012), the labour force as of 2011 stood at 67.3 million. The labour force participation rate computed as the economically active population aged 15-64 in the labour market has been stable at about 73\% from 2006-2011 (NBS, 2012). This figure suggests that around three-quarters of Nigeria's economically active population participate in economic activities.

Although Nigeria's labour force participation rate remained flat at about three-quarters of the entire economically active population, national unemployment rate nevertheless increased from 12.7 per cent in 2007 to 23.9 per cent in 2011 and further to 27.4 per cent in 2012. Appendix 1 shows the labour force participation and unemployment rates from 1999-2012, while Appendix 2 shows the growth pattern of the labour force and employment from 2007-2011.

Appendices 1 and 2 clearly show that unemployment in Nigeria has been on the rise since 1999. This is contrast to growth in employment creation over the same period. Although Appendix 1 depicts a picture of stable aggregate unemployment rate from 1999 to 2012, these figures however mask the rising youth unemployment profile in Nigeria.

Youth unemployment as a component of aggregate unemployment is crucial in explaining the rise of terrorism in Nigeria. Although Appendix 1 depicts a picture of stable aggregate unemployment rates from 1999 to 2012, these figures however mask the rising youth unemployment profile in Nigeria. Appendix 3 shows the divergence in aggregate unemployment and youth unemployment rates in Nigeria from 1999-2012, while Appendix 4 shows the national unemployment data disaggregated by geopolitical zones. The disaggregation is carried out to clearly show the level of unemployment incidence according to geopolitical zones.

Appendices 3 and 4 shows that youth unemployment is rising more rapidly than aggregate unemployment rate, while the latter shows that within the sample period (2006-2010), the prevalence of unemployment was highest in the NorthWest and North-East geopolitical zones, especially in 2010. Not surprisingly, the North-East, North-West and NorthCentral have been the hotbed for the Islamic terrorist activities of Boko Haram and Ansaru.

\subsection{Performance of the Nigerian Economy}

Nigeria's economic performance has been impressive since the transition to democracy in 1999. The economy grew at a dramatic rate from 2001, making it the fifth fastest growing economy in the world in 2010, at an economic growth rate of $7.8 \%$. 
Also, after rebasing the economy in 2014, Nigeria became the largest economy in Africa and the $26^{\text {th }}$ biggest economy in the world with a GDP of $\$ 509.9$ billion for 2013 (Oguntuase, 2014). Appendices 5 and 6 shows that Nigeria's GDP and economic growth rate has grown considerably since its independence in 1960. Nigeria's economic growth has mainly been driven by petrodollars from crude oil and natural gas exports.

This trend has changed within the past decade (2001-2011). Available evidence shows that non-oil GDP growth rate has surpassed the oil-GDP growth rate (CBN, 2011). This means that the efforts of the Nigerian government to diversify the economy from dependence on oil revenue has paid off, given that non-oil GDP growth rate increased from 3\% in 2000 to around 9\% in 2011 (Appendix 6).

Moreover, the main drivers of growth in the non-oil sector have been Agriculture, commerce (wholesale and retail) and services. When the non-oil GDP growth rate is further disaggregated, agriculture becomes the highest growth contributor with 2 to $3 \%$. This is followed by wholesale and retails with a growth rate of 1 to $2 \%$, while the services sector records the fastest growth rate (see Appendix 7).

Additionally, given that the Nigerian economy has structurally transited from an agrarian economy to a service-based economy (after rebasing in 2014), we present the sectoral distribution of output and employment generated for each sector of the economy. The structural evolution is represented in Appendices 8 and 9.

As it is previously mentioned, since Nigeria's transition to democratic rule in 1999, the country has witnessed robust economic growth averaging $7.8 \%$. However, over the same period, the level of poverty rose significantly. The National Bureau of Statistics (NBS, 2010) estimates that from 2004 to 2010, poverty measured by adjusted dollar per day rose by $3.1 \%$ per annum.

The incidence of poverty in Nigeria varies according to geopolitical zones. This is corroborated by Ichoku, Agu and Ataguba (2012) and Aigbokan (2008) who observe that the distribution of poverty incidence varies significantly across various geopolitical zones in Nigeria. Appendix 10 presents the incidence of poverty in Nigeria between 2004 and 2010 - measured by the percentage of households who live below $\$ 1.25$ a day.

The figures show that the incidence of poverty is greater in rural areas (66.3\%) than in urban areas (52.4\%). More so, when examined at the geopolitical level, Appendix 10 show that the Northern geopolitical zones are comparatively poorer than their counterparts in the South. Appendix 10 also shows that the level of poverty in Southern Nigeria has increased between 2000 and 2010. For instance, the poverty level in the South-East geopolitical zone has increased by $89.72 \%$. Hence, despite that the Northern region is poorer when compared to the Southern region; available evidence nevertheless shows that the two regions are getting poorer. Appendix 10represents Appendix 11 graphically.

The level of income inequality in Nigeria has also increased since the last decade. For 2004 and 2010, the Gini Index shows that inequality in Nigeria has increased by $4.1 \%$. Notably, the changes in the national rate of inequality arise mainly from urban inequality (4.2\%) in contrast to rural inequality (2.2\%). Appendix 12 and Appendix 13 show the income inequality in Northern Nigeria between 2004 and 2010. Appendix 14 presents the percentage growth in economic development in the three geopolitical zones in Northern Nigeria. An important point from this figure is that the North-East geopolitical zone which has been the hotbed of terrorist attacks since 2009 has the highest level of income inequality in Nigeria.

\section{Methodology and Empirical Framework}

The study is conducted at the country-level (Nigeria) and the estimation sample spans from 1970 to 2013. The study uses the yearly count of terrorist incidents in Nigeria $(n)$ at year $t_{t}\left(Y_{t}^{n}\right)$ as the dependent variable. The Global Terrorism Database (GTD) from the National Consortium for the Study of Terrorism and Responses to Terrorism (START) at the University of Maryland constitutes the data source for terrorism in the analysis. The GTD is the most recent and detailed database on international and domestic terrorist events. It includes date, country, and location of attacks, target types, attack types, weapon types; nationality and terror groups responsible.

The study categorizes independent variables into political and socio-economic variables, while leaving out the demographic variables from empirical analysis. The political variables include democratic participation, political competition, and competitiveness of political participation, restriction of political participation, executive constraints, and regime duration. To operationalize these variables, the study uses the Freedom House Index (FHI) for political rights and liberties as a proxy for democratic participation.

The FHI varies from 1 to 7 , where 1 is an indication of completely free regimes (maximum), whereas 7 depict regimes that are completely not free (minimum). As a robustness check for democratic participation, the study equally uses the polity2 variable which measures the decree of democratization. The studyoperationalizes this process by subtracting the AUTOC from the DEMOC variable in the Polity IV database. 
According to Marshall, Gurr and Jaggers (2014), this process provides a single regime score that ranges from +10 (full democracy) to -10 (full autocracy). In the empirical analysis, the study also examines the significance of the DEMOC and AUTOC variables separately.

Furthermore, the study operationalizes political competition by using the POLCOMP variables of the Polity IV Project. Marshal et al (2014) explains that POLCOMP measures two dimensions of political competition. The first component measures degree of institutionalization (political regulation) and competiveness of political participation (PARCOMP), while the second measures the extent of government restriction on political competition (PERREG). The Polity IV concept of political competition (POLCOMP) varies on a scale of 1-10, where 1 defines suppressed political competition and 10 describes institutionalized electoral political competition.

The other remaining political variables, namely, executive constraints (decision rules) and regime duration were derived from the Polity IV Project database. Executive constraint is measured by the Polity IV variable: XCONST. Marshal et al (2014:24) defines the variable as 'the extent of institutionalized constraints on the decision-making powers of the chief executives, whether individuals or collectivities.' In the context of our study, this may comprise constraints on the executive arm of government by the legislature (state and federal), and other kinds of accountability groups like the Nigerian Council of State, the Judiciary, monarchies and ruling parties like the Peoples Democratic Party (PDP) and the All Progressives Congress (APC). Generally, the variable measures the level of checks and balances in the decision making processes of a polity. The variable is scaled from 1 (unlimited authority) to 7 (executive parity or subordination). Last, the study measures regime duration using the DURABLE variable. The variable provides a running measure of the durability of a regimes authority pattern for a given year, meaning the number of substantive changes in authority characteristics. The variable is defined as a 3-point change in the POLITY score over a period of three years or less (Marshal et al, 2014).

Regarding the socio-economic explanatory variables, the study uses the logged GDP per capita (constant 2005 USD) of Nigeria, GDP per capita growth rate, trade openness and unemployment to measure the level of poverty and socioeconomic development. Data for these variables are sourced from the World Development Indicators (WDI) database of the World Bank and NOIPolls Limited. The study does not include other socio-economic variables such as annual income inequality (proxied by Gini-coefficient) and national unemployment rate due to limitations in data availability.

\subsection{Econometric Model Specification}

The study investigates the relationship between political and socio-economic characteristics on the yearly counts of terrorist incidents in Nigeria from 1970-2013. Given that the counts of terrorist incidents exhibits over-dispersion (that is, it has significantly larger variance than the mean, cf. Appendix 15); the study uses the Negative Binomial Model (NB) as the appropriate empirical strategy to test the hypotheses, except for hypothesis 5. To test hypothesis 5, the study uses the Nationwide Opinion Poll on Security conducted by NOIPolls Limited in the Week of 21, July 2014. The opinion poll presents an opportunity to validate the findings of our econometric model with the perception of Nigerians.

The study estimates the NB Model following the method of Matt Golder (2003). The probability distribution of the NB model is of the following form:

$$
\operatorname{Pr}\left(Y_{t}^{n}=y_{t}^{n} \mid \boldsymbol{X}_{t}, \delta\right)=\frac{\Gamma\left(y_{t}^{n}+\delta\right)}{\Gamma(\delta) \Gamma\left(y_{t+1}^{n}\right)}\left(\frac{\delta}{\delta+\mu_{t}}\right)^{\delta}\left(\frac{\mu_{t}}{\delta+\mu_{t}}\right)^{y_{t}^{n}} \ldots \ldots \ldots \ldots \ldots \ldots \ldots \ldots(1)
$$

\section{Analysis and Discussion of Results}

Appendix 15 presents the descriptive statistics of all variables under examination.Using the data described in the preceding sections, several NB regressions are used to assess the validity of the study's hypotheses. To test the hypotheses, the study first run a baseline model specification (Appendix 16) that includes all the independent variables, with total counts of terrorist incidents as the dependent variable. Also, following Abadie (2006), the study conducts a robustness exercise for the regressions in the baseline model by using the total number of fatalities (deaths) caused by terrorist incidents as the response variable (results are presented in Appendix 17). The variable was derived from the Global Terrorism Database and spans from 1970 to 2013.

The results in Appendices 16 and 17 are presented in the form of incidence rate ratios (IRR). The IRR's show by what factor (or percent) the expected terrorist incidents (or fatalities) increase in an explanatory variable. When values are smaller than one, it indicates a negative effect on terrorist incidents (or fatalities), whereas, when the value is greater than one it indicates that there is a positive effect on the dependent variable. The results of the baseline model are presented in Appendix 16, and the core findings are the following. 
First, we do not find empirical support for the first thesis that greater democratic participation reduces the number of terrorist incidents in Nigeria. This finding is ambiguous when an alternative variable for democratic participation (Polity2 variable) is considered.

In more detail, Model 1 and 2 in Table 5 show that the proxies for democratic participation are positively related to terrorist incidents when regressed with socio-economic variables, although this relationship is not statistically significant. For instance, a one per cent increase in democratic participation in model 1 and 2 increases the estimated incidence rate of terrorist incidents by a factor of 1.89 (89 per cent) and 1.61 (61 per cent) respectively, all other variables being constant.

When democratic participation is regressed withpolitical variables (Model 4), the study find that the positive relationship becomes statistical significant at 1,5 and 10 per cent - thus, corresponding to the findings of Chenoweth (2010). The study's finding on the relationship between democratic participation and terrorism shows that there is no evidence to support the Bush Doctrine ideology in terms of applicability to Nigeria.

Model 1, 3 and 4 estimate a negative binomial regression testing hypothesis 2, which conjectures that political competition increases terrorism in Nigeria. Across all three models, the study find evidence to support the hypothesis that political competition is a significant and robust positive predictor of terrorism in Nigeria. The IRR's show that a one-unit increase in political competition in model 1, 3 and 4 increases the occurrence of terrorist incidents by a factor of 3.4 (240 per cent), 3.52 (252 per cent) and 5.62 (462 per cent) respectively, keeping other explanatory variables constant. This finding is consistent with other studies that find a significant and positive relationship between political competition and terrorism.

Further, to test the third hypothesis that there is a positive relationship between executive constraint and terrorism in Nigeria, Nigeria the negative binomial regression estimates of model 1, and 2 (Appendix 17) shows that a one unit increase in executive constraint reduces terrorist incidents in by a factor of 0.5 (50 per cent), 0.24 (76 per cent) and 0.51 (49 per cent) for models 1,2 and 3. That is, there is strong evidence that institutional constraints (executive constraint) have a significant relationship with terrorist incidents.

On the relationship between terrorism and socio-economic variables in Nigeria, the NB models test hypothesis 4 which postulates that higher economic development reduces terrorism. As shown in Appendix 17, GDP per-capita is found to be positive and significant with terrorist incidents in all the estimations (model 1, 2, 4, and 6).

The results on the relationship between economic prosperity (GDP per-capita) and terrorism corroborate the findings in the literature that poverty is not a root cause of terrorism in Nigeria (cf., Kis-Katos, Liebert and Schulze, 2014; Freytag, Kruger, Meierrieks, and Schneider, 2011; and Piazza, 2008). Model 1, 2 and 8 in Appendix 16 presents the NB estimates for economic growth (GDP percapita growth). The model results for the relationship between economic prosperity and terrorism corroborates the findings in the literature that poverty is not a root cause of terrorism in Nigeria.

Economic growth is used to account for modernization pressures and changes in economic conditions. The finding shows that across all models $(1,2,6)$, a one per cent increase in GDP per capita growth reduces terrorist incidents by an average of 5 per cent, all other predictor variables held constant. These results therefore indicate that economic growth has a significant positive relationship with terrorist incidents, even though this effect is small.

Furthermore, the study presents the following findings on the relationship between terrorism and other variables as displayed in Appendix 17:The finding on trade openness, which measures the level of socio-economic development and short-run economic performance (Model 6 and 7 in Appendix 17) indicates that trade openness has a positive and significant effect on terrorist incidents in Nigeria, although the magnitude is not sizeable. For instance, in terms of IRRs, increasing trade openness by one per cent increases the estimated rate of terrorist incidents by 4 percent for Model 6 and 3 percent for model 7, other variables held constant. This finding contradicts the existing literature which opines that trade openness reduces the occurrence of terrorist indents (cf. Levine and Renelt, 1992; and Li and Schaub, 2004), there is one plausible explanation for this deviation. Nigeria shares international boundaries with Chad, Benin, Cameroun and Niger. These countries in turn share borders with conflict afflicted countries like Libya, Mali, Sudan and Central African Republic (CAR). Due to these countries generally have porous borders, looted arms and ammunitions during violent conflicts often find their way into Nigeria. This is true when viewed against the backdrop of civil wars and violent conflicts that occurred in Libya and Mali within the past years. For instance, the Arab Spring in Libya which led to a civil war that overthrew Muammar Gaddafi in 2011 facilitated the looting of arms and ammunitions by rebel factions and terrorist groups. Another significant event that may have led to arms smuggling into Nigeria was the French military intervention to regain control of Northern Mali from terrorist groups in 2013. 
The intervention was an aftermath of a 2012 military coup d'état which gradually led to the loss of Northern Mali to the National Movement for the Liberation of Azawad with the support of Islamic terrorist groups like Ansar Dine and AlQaeda in the Islamic Maghreb (AQIM).

Moreover, civil liberty is shown to significantly increase the number of terrorist incidents in Nigeria. Model 5 in Table 6 points out that a one-unit increase in civil liberty score increases terrorist incidents by a factor of 4.07 (307 per cent), all other explanatory variables held constant.

The results of the models on political rights are mixed and thus inconclusive. The study shows that regime durability has a significant and positive effect on terrorism across all the models. The positive relationship between regime durability can be explained when one considers the level of inter-ethnic is considered. In Nigeria, ethnic diversity fuels mutual distrust and suspicion, and is one of the main causes of political rivalry. Given this, democratic and military regimes often face violent resentments from other ethnic groups irrespective of how durable the political system has been in existence. Theoretically speaking, this raises the likelihood of terrorist incidents even with durable regimes.

In summary, the study finds that the competitiveness of political participation has a positive relationship and insignificant relationship with terrorist incidents. The finding is in line with the results presented earlier that political competition dramatically increases terrorist incidents in Nigeria.

\subsection{Robustness Checks}

To check the validity of the baseline specification results, the study conducted a robustness check by only replacing the baseline independent variable (number of terrorist incidents) with a new independent variable: The yearly number of fatalities from terrorist incidents in Nigeria from 1970 to 2013 (cf. Abadie, 2006). The NB regression results for this exercise are presented in Appendix 17. Overall, the findings are robust and similar to the baseline specification results.

\subsection{Nationwide Security Opinion Poll on the Root Causes of Terrorism in Nigeria}

To further explore the socio-economic and political causes of terrorism in Nigeria, the study uses a nationwide security opinion poll conducted by NOIPolls Limited in the week of 21 July, 2014 in order to gauge the perception of Nigerians on terrorism. Specifically, the study tests the last hypothesis that the high prevalence of unemployment is a root cause of terrorism in Nigeria.

The opinion poll comprised telephone interviews of a random nationwide sample of 1000 phone-owning Nigerians aged 18 and above. The sample represents the six geo-political zones of Nigeria. According to NOIPolls (2014), with a 95 per cent confidence interval the polls results are statistically significant within the range of $+/-3$ per cent.

Whereas the Security Opinion Poll comprises a questionnaire of six questions, the study uses only thesecond question to conduct its analysis. Question two poses the following question to respondents: In your opinion, what is the major cause of terrorism in Nigeria? The rationale for using the open-ended question format is to appropriately gauge the perception of respondents without producing a bias in response. Appendix 18 represents the results from question two of the nationwide security opinion poll.

According to the Appendix 18, 26 per cent of respondents claim that 'Election/Political Interest' is the main root cause of terrorism in Nigeria. This perception is robust and affirms our earlier finding (using the NB model) that political competition has a positive and significant relationship with terrorism in Nigeria. Following from election/political interest, 21 per cent of respondents in the poll attribute unemployment to be the next major cause of terrorism in Nigeria. This finding supports our last hypothesis that the high prevalence of unemployment is a positive and significant explanation to the occurrence of terrorism in Nigeria. When analyzed in closer detail, other interesting findings from the polls follow. Appendix 18 shows that respondents within the age bracket of 18-21 (40 per cent) perceive unemployment as the major cause of terrorism, whereas the older age category (60 years and above) make up 43 per cent of respondents who indicate that election/political interest is the main cause of terrorism in Nigeria.

Other important findings from the poll are that respondents from the most impoverished geopolitical zones of Nigeria (North-East and North-West and North-Central) perceive unemployment to be the main cause of terrorism (32, 27 and 24 per cent respectively), while the respondents from the economically well-off geopolitical zones (i.e. South-West) perceive that unemployment is not a significant cause of terrorism.

\section{Conclusion and Suggestions}

This study analyzed the association between terrorism and democracy in Nigeria from 1970 to 2013. The study equally investigated the relationship between terrorism and socio-economic variables in Nigeria. In examining the study's hypothesis, the study constructed a country-level dataset comprising variables from the GTD, Freedom House, Polity Project and World Bank Indicators (WDI). 
Using a Negative Binomial Regression Model which accounts for over-dispersion of the dependent variable (yearly counts of terrorist incidents and fatalities), the study established that in the context of Nigeria, greater democratic participation does not reduce the incidence of terrorism. The study also finds that political competition is the only factor that dramatically increases the occurrence of terrorism in Nigeria.

Furthermore, the study uncovered what has been overlooked by other scholars, especially in the context of ethnically diverse developing countries like Nigeria: the effect of executive constraint on terrorism. The study's findings suggest that institutional constraint on the executive has a negative and significant relationship with terrorist activities. On the relationship between terrorism and socio-economic variables, the study finds that in general economic development does not reduce the occurrence of terrorism in Nigeria. The policy implications of these conclusions are stark. First, it calls into question the validity of the proposition that promoting democracy is an anti-terrorism strategy, especially in developing countries. Second, given the findings on political competition, the study suggests that the Nigerian government should create a more stable and inclusive political environment that upholds the principles of equity and fairness for political participants and actors.

\section{References}

Abadie, A. (2006). Poverty, political freedom, and the roots of terrorism. American Economic Review Papers and Proceedings, 96, 50-56.

Ajayi, A.I. (2012). Boko haram and terrorism in Nigeria: exploratory and explanatory notes. Global Advanced Research Journal of History, Political Science and International Relations 1(5), 103-107.

Chenoweth, E. (2010). Democratic competition and terrorist activity.Journal of Politics, 77(1), 16-30.

Freytag, A., Kruger, J., Meierrieks, D., and Scneider, F. (2011). The origins of terrorism: cross country estimates of socio-economic determinants of terrorism. European Journal of Political Economy, 27, S5-S16.

Hamilton, L. C. and Hamilton, J.D. (1983). Dynamics of terrorism. International Studies Quarterly 27, 39-54.

Ichoku, E. H.,Agu, C., and Ataguba, E. J. (2012). What do we know about pro-poor growth and regional poverty in Nigeria? International Journal of Economic Sciences and Applied Research, 5(3), 147-172.

Lai, B. (2007). Draining the swamp: an empirical examination of the production of international terrorism, 1968-1998. Conflict Management and Peace Science 24, 297-310.

Levine, R. andRenelt, D. (1992). A sensitivity analysis of cross-country growth regressions. The American Economic Review, 82, 942-963.

Li, Q. (2005). Does democracy promote transnational terrorist incidents? Journal of Conflict Resolution, 49(2), 278297. In: Sandler, T. (2013) The Analytical Study of Terrorism: Taking Stock. International Journal of Peace Research, 51 (2), 257-271.

Marshall, M, G., Gurr, T, R., and Jaggers, K. (2014). Polity IV project: political regime characteristics and transitions, 1800-2013, dataset user's manual. Center for Systemic Peace and Societal-Systems Research Inc.

Matt, G. (2003). Course material on multichotomous dependent variables III. New York University (NYC). Available from: <https://files.nyu.edu/mrg217/public/count.pdf> [Accessed 6 August, 2014].

National Bureau of Statistics (2012). National accounts (1981-2012): various issues. NBS, Abuja.

National Bureau of Statistics (2010). Annual abstract of statistics. NBS, Abuja.

Newman, P. (2013). The etymology of Hausa Boko. Mega-Chad Research Network http://lah.soas.ac.uk/projects/megachad/publications/Newman-2013-Etymology-of Hausaboko.

Oguntuase, O. (2014). Rebased GDP: Nigeria's new status is not a mirage. Business Day. Available from <http://businessdayonline.com/2014/05/rebased-gdp-nigerias-new-status-is-not-amirage/\#.U7bPM_ldWHw> [Accessed 4 July, 2014].

Oyovbaire, S. E. (1980). The atlantic ocean, Gaddafi, Maitatsine and rice-on national security and Nigeria's African policy. Nigeria Journal of International Studies, 4, $1-2$.

Piazza, J. A. (2006). Rooted in poverty? terrorism, poor economic development, and social cleavages. Terrorism and Political Violence, 18(1), 159-177.

Piazza, J. A. (2008). Do democracy and free markets protect us from terrorism? International Politics 45(1), 72-91.

PRB (2012). World population data sheet. http://www.prb.org/pdf12/2012-population-data-sheet_eng.pdf

Stephen, D. (2009). Nigeria prospects for peace in the niger delta. In: Boye R. R. (2012) Nigeria Antiterrorism Law and Global Security. Mimeo, Department of Political Science, Yobe State University, Nigeria. 


\section{Appendices}

Appendix 1: Labour Force Participation and Unemployment Rates for Nigeria (1999-2012)

\begin{tabular}{|c|c|c|c|c|}
\hline & & & Une & \\
\hline Year & LFP & GHS, NLSS & ILO & NBS \\
\hline 1999 & 74.7 & 2.2 & & 8.2 \\
\hline 2000 & & & & 13.1 \\
\hline 2001 & & & & 13.6 \\
\hline 2002 & & & & 12.6 \\
\hline 2003 & & & 2.9 & 14.8 \\
\hline 2004 & 77.0 & 3.0 & 2.8 & 13.4 \\
\hline 2005 & & & 3.3 & 11.9 \\
\hline 2006 & 74.8 & 2.6 & 3.5 & 12.3 \\
\hline 2007 & 72.8 & & 3.5 & 12.7 \\
\hline 2008 & 73.7 & & & 14.9 \\
\hline 2009 & 72.8 & & & 19.7 \\
\hline 2010 & 72.8 & & & 21.4 \\
\hline 2011 & 72.8 & & & 23.9 \\
\hline 2012 & $72.8^{*}$ & & & 27.4 \\
\hline
\end{tabular}

Note: Labour force participation and unemployment rates (GHS, NLSS) for 1999-2006 were obtained from Haywood and Teal (2010). The remaining statistics were obtained from NBS and computed by the author. *estimates

Appendix 2: Labour Force Growth Rate, Job Growth Rate and New Unemployment

\begin{tabular}{|l|l|l|l|}
\hline Year & Labour Force Growth (\%) & Employment Growth (\%) & Newly Unemployed (millions) \\
\hline $\mathbf{2 0 0 7}$ & 3.2 & 2.7 & 0.46 \\
\hline $\mathbf{2 0 0 8}$ & 3.2 & 0.6 & 1.59 \\
\hline $\mathbf{2 0 0 9}$ & 3.2 & -2.6 & 3.32 \\
\hline $\mathbf{2 0 1 0}$ & 3.2 & 1.0 & 1.51 \\
\hline $\mathbf{2 0 1 1}$ & 3.2 & -0.1 & 2.13 \\
\hline
\end{tabular}

Note: All figures are in percentages except otherwise indicated. Authors' calculation from NBS (2012).

\section{Appendix 3: Aggregate Unemployment versus Youth Unemployment in Nigeria}

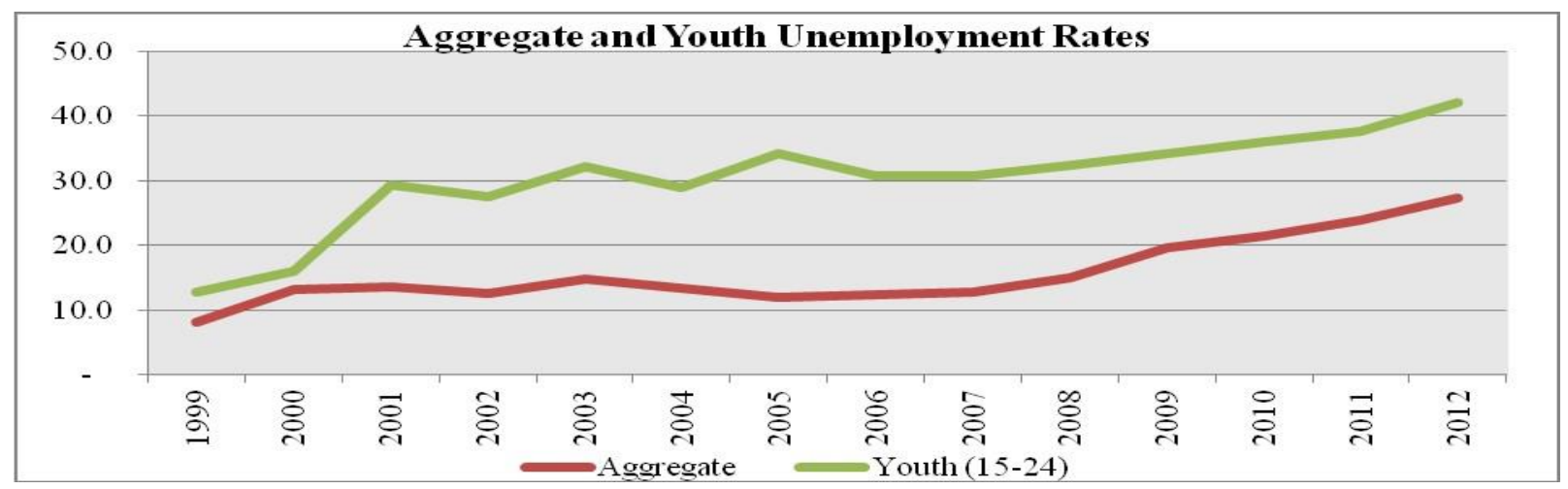

Notes: The unemployment rates used to compute Figure 1 are derived from various NBS Annual Abstracts of Statistics. 
Appendix 4: Unemployment Rate by Geopolitical Zone (2006-2010)

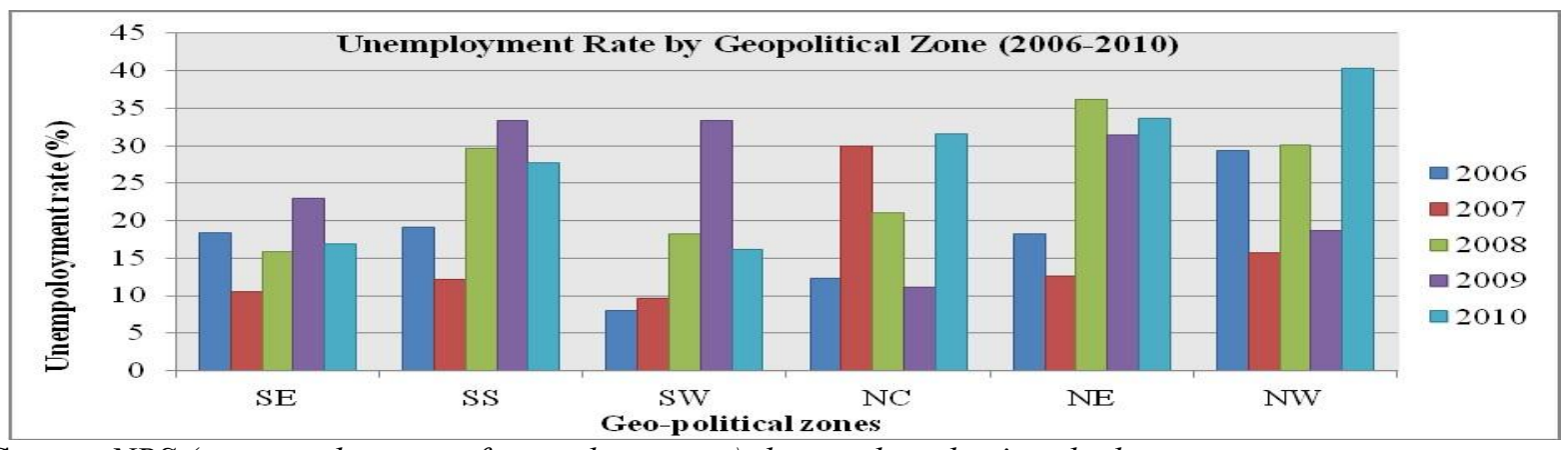

Source:NBS (various abstracts of annual statistics) data with author's calculation

\section{Appendix 5: Nigeria's GDP (1960-2011, N'millions)}

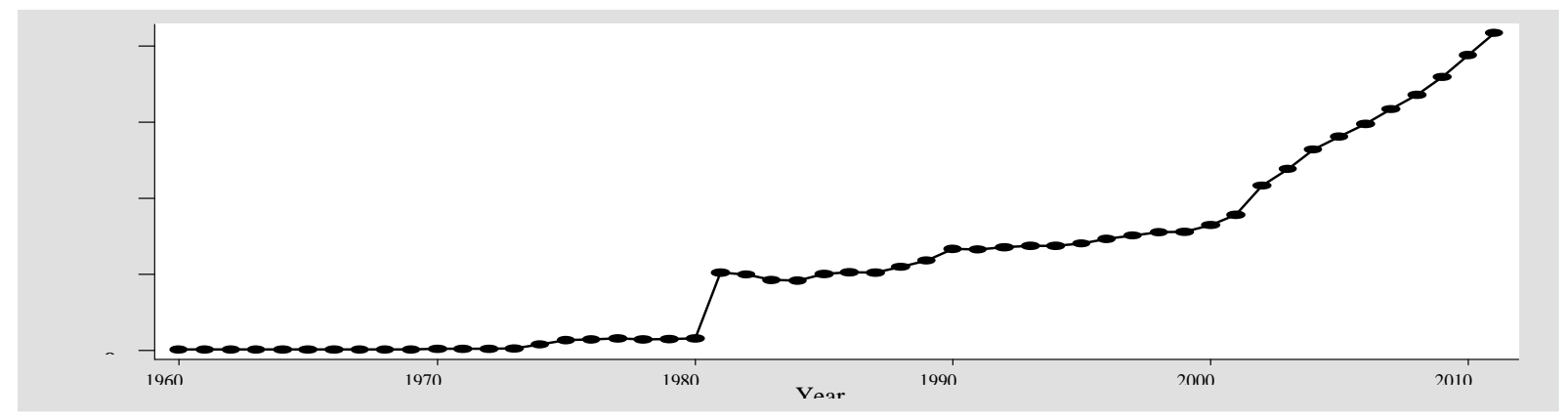

Source:CBN Statistical Bulletin, 2011

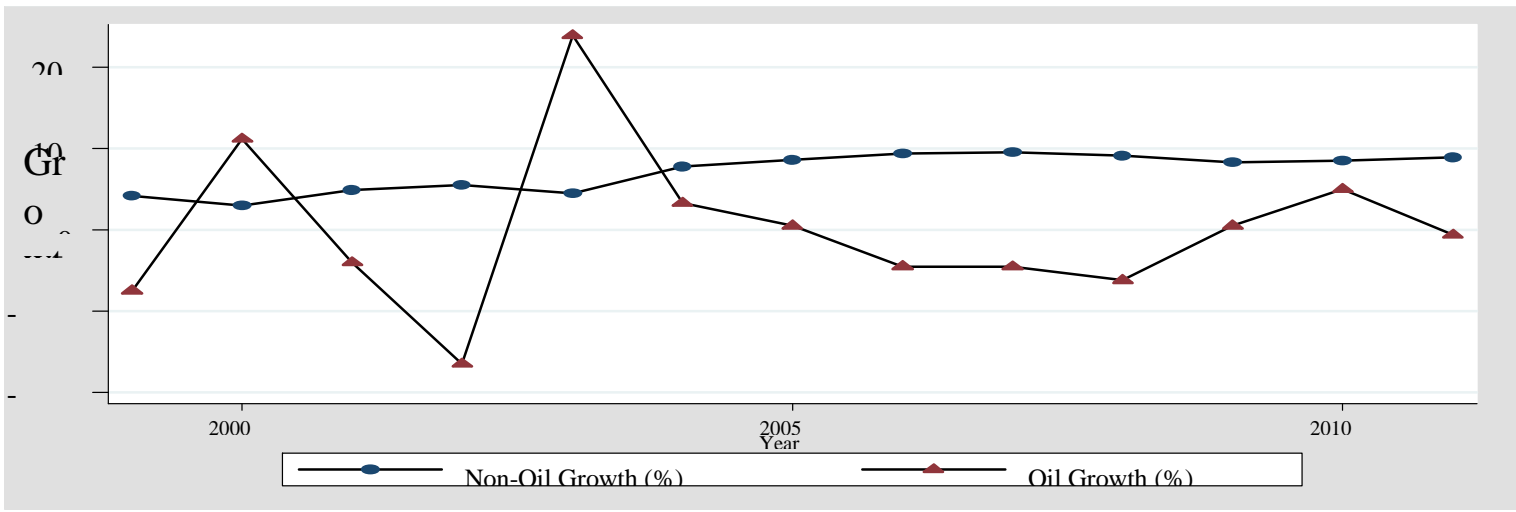

Annendix 6: Oil and Nefil GDP Growth (1999-2011)

Source:CBN Statistical Bulletin, 2011

Appendix 7: Growth Rate of the Non-Oil Sector in Nigeria (2004-2011)

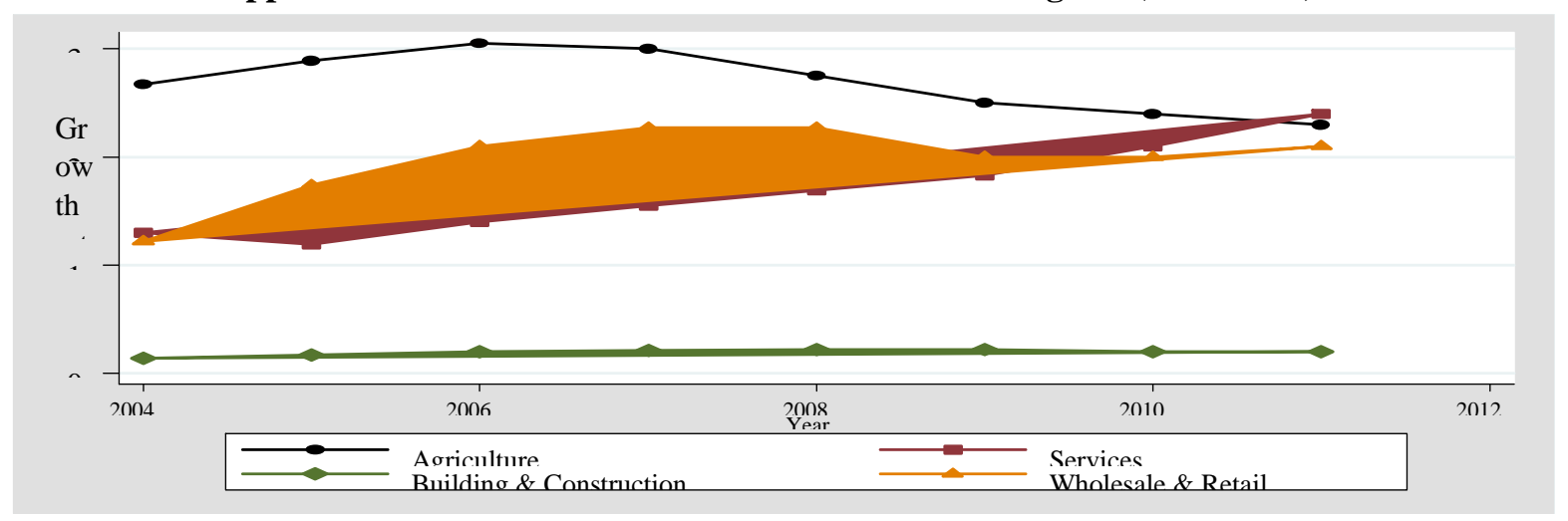


Appendix 8: Changes in Sectoral Distribution of Output (1970-2012)

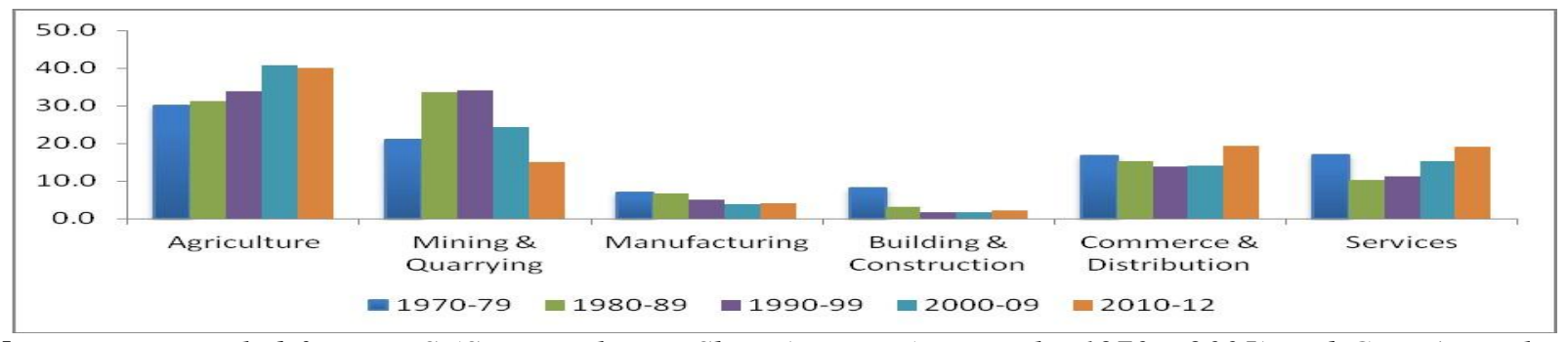
(2012)

Note:Data compiled from NBS (Statistical Fact Sheets), NMB (Data File, 1970 - 2005) and CBN Annual Report

Appendix 9: Changes in Sectoral Distribution of Employment

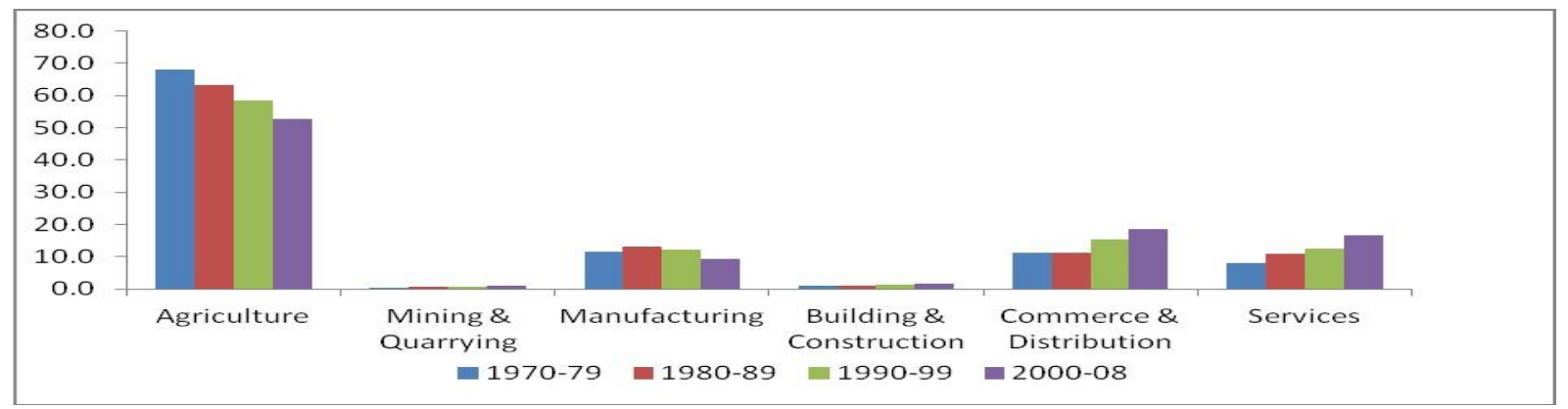

Note:Employment data is compiled from the National Rolling Plan (1980 - 2003), NBS (Statistical Fact Sheets), NMB (Data File, 1970 - 2005) and CBN Annual Report (2012). Employment data series were available up to 2008.

Appendix 10: Incidence of Poverty in Nigeria (\$1.25 per day, 2004-2010)

\begin{tabular}{|l|l|l|l|}
\hline & $\mathbf{2 0 0 4}$ & $\mathbf{2 0 1 0}$ & \% Change \\
\hline National & 51.6 & 61.2 & 18.60 \\
\hline Urban & 40.1 & 52.4 & 30.67 \\
\hline Rural & 60.6 & 66.3 & 9.41 \\
\hline Geo-Political Zones & & & \\
\hline North-Central & 58.6 & 59.7 & 1.88 \\
\hline North-East & 64.8 & 69.1 & 6.64 \\
\hline North-West & 61.2 & 70.4 & 15.03 \\
\hline South-East & 31.2 & 59.2 & 89.74 \\
\hline South-South & 57.6 & 56.1 & 17.86 \\
\hline South-West & 40.2 & 50.1 & 24.63 \\
\hline
\end{tabular}

Source: National Bureau of Statistics Annual Abstract of Statistics (2011) data with author's calculation. All figures in Appendix 2 are in percentages.

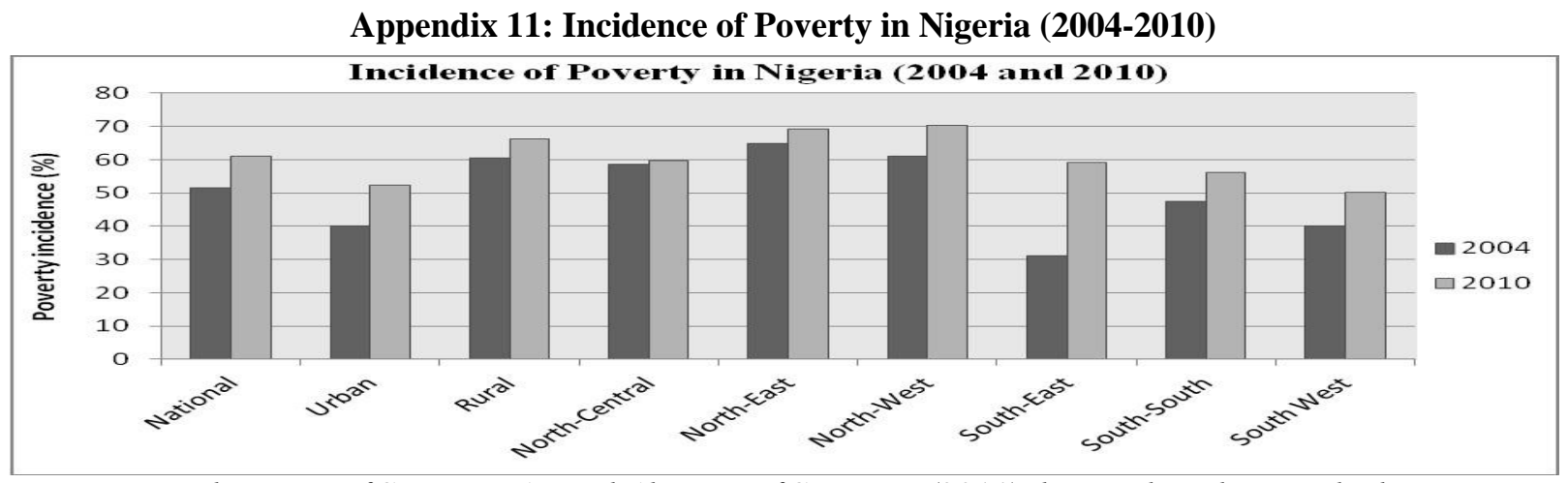

Source:National Bureau of Statistics Annual Abstract of Statistics (2011) data with author's calculation 
Appendix12: Income Inequality in Nigeria (2004-2010)

\begin{tabular}{|l|l|l|l|}
\hline & $\mathbf{2 0 0 4}$ & $\mathbf{2 0 1 0}$ & \% Change \\
\hline National & 0.4296 & 0.4470 & 4.1 \\
\hline Urban & 0.4154 & 0.4328 & 4.2 \\
\hline Rural & 0.4239 & 0.4334 & 2.2 \\
\hline Geo-Political Zones & & & \\
\hline North-Central & 0.4459 & 0.4220 & -5.4 \\
\hline North-East & 0.4114 & 0.4468 & 8.6 \\
\hline North-West & 0.4028 & 0.4056 & 0.7 \\
\hline South-East & 0.3760 & 0.4442 & 18.1 \\
\hline South-South & 0.3849 & 0.4340 & 12.8 \\
\hline South-West & 0.4088 & 0.4097 & 0.2 \\
\hline
\end{tabular}

Source: National Bureau of Statistics Annual Abstract of Statistics (2011) with author's calculation. The GiniCoefficient ranks income inequality on a $0-1$ scale, with 0 meaning perfect equality and 1 meaning perfect inequality. Figures closer to 1 shows higher inequality, while figures closer to 1 show the reverse of the former.

Appendix 13: Income Inequality in Northern Nigeria

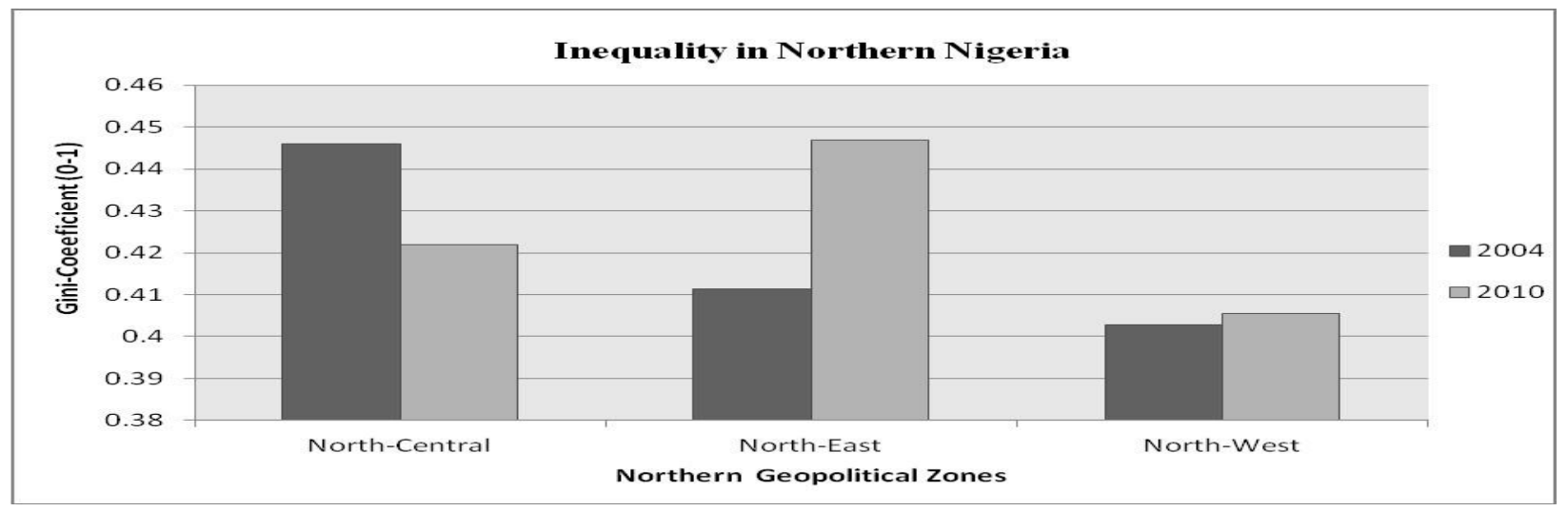

Appendix 14: \% Growth in inequality in Nigeria

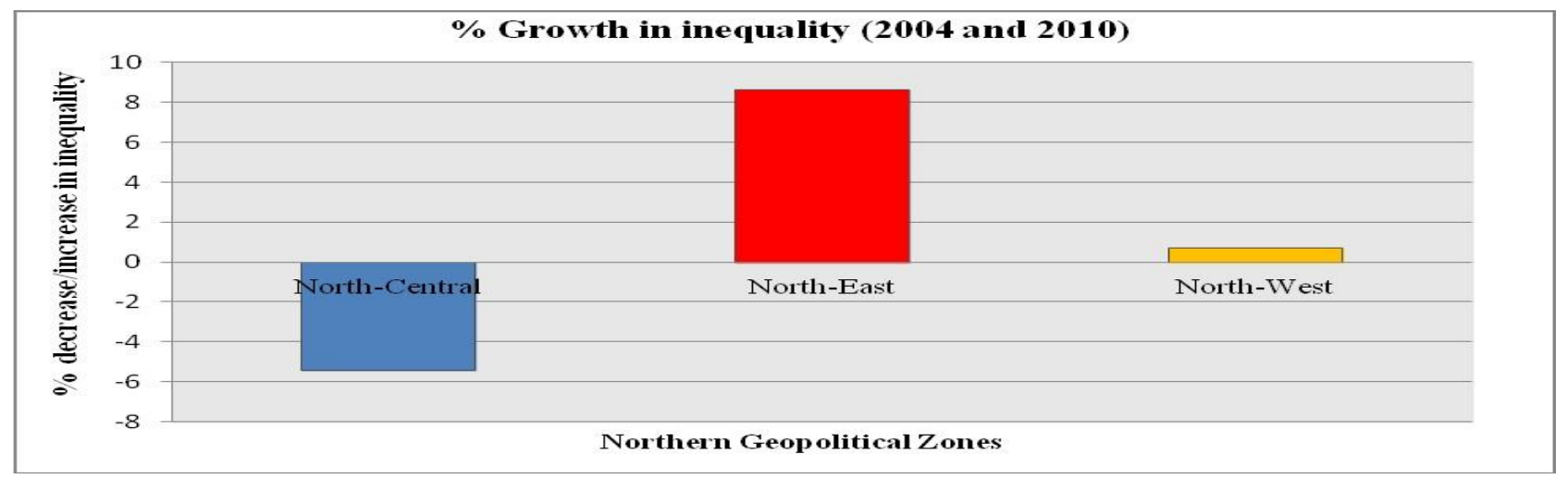

Appendix 15: Descriptive Statistics
\begin{tabular}{|l|l|l|l|l|l|}
\hline Variable & No. Obs. & Mean & Std. Dev. & Min. & Max. \\
\hline Total No. of Terrorist Events & 44 & 34.43 & 104.38 & 0 & 597 \\
\hline Total No. of Fatalities & 44 & 113.84 & 357.80 & 0 & 2000 \\
\hline Log of GDP Per Capita & 44 & 24.96 & 0.43 & 24.39 & 25.97 \\
\hline GDP Growth & 44 & 4.50 & 8.10 & -13.13 & 33.74 \\
\hline Trade Openness & 44 & 48.79 & 15.98 & 19.62 & 81.81 \\
\hline Democracy & 44 & -1.73 & 19.24 & -88.00 & 8.00 \\
\hline Autocracy & 44 & -0.64 & 19.54 & -88.00 & 7.00 \\
\hline Political Competition & 44 & -0.86 & 19.33 & -88.00 & 6.00 \\
\hline Competitiveness of Political & 44 & -3.00 & 18.79 & -88.00 & 3.00 \\
\hline
\end{tabular}




\begin{tabular}{|l|l|l|l|l|l|}
\hline Participation (PARCOMP) & & & & & \\
\hline $\begin{array}{l}\text { Restriction of Political } \\
\text { Participation (PERREG) }\end{array}$ & 44 & -1.07 & 19.21 & -88.00 & 4.00 \\
\hline Regime Durability & 44 & 6.05 & 4.17 & 0.00 & 14.00 \\
\hline Political Rights & 44 & 4.95 & 1.52 & 2.00 & 7.00 \\
\hline Civil Liberties & 44 & 4.32 & 0.91 & 3.00 & 7.00 \\
\hline $\begin{array}{l}\text { Democratic Participation (Polity2 } \\
\text { Variable) }\end{array}$ & 43 & -1.12 & 5.72 & -7.00 & 7.00 \\
\hline $\begin{array}{l}\text { Democratic Participation } \\
\text { (Freedom House Index) }\end{array}$ & 44 & 4.64 & 1.13 & 2.50 & 7.00 \\
\hline Executive Constraint & 44 & -1.00 & 19.34 & -88.00 & 7.00 \\
\hline
\end{tabular}

Note:Data was sourced from GTD, Freedom House, Polity IV and WDI, with author's STATA Computation.

Appendix16: Negative Binomial Estimation Results (baseline specification results)

\begin{tabular}{|c|c|c|c|c|c|c|c|c|c|}
\hline \multicolumn{3}{|l|}{ Dependent Variable } & \multicolumn{7}{|c|}{ (Total Counts of Terrorism in Nigeria, 1970-2013) } \\
\hline $\begin{array}{l}\text { Independent Variables } \\
\text {. }\end{array}$ & Model 1 & Model 2 & Model 3 & Model 4 & Model 5 & Model 6 & Model 7 & Model 8 & Model 9 \\
\hline Log of GDP & $\begin{array}{l}57.52 * * * \\
{[28.59]}\end{array}$ & $\begin{array}{l}51.78 * * * \\
{[25.14]}\end{array}$ & $\begin{array}{l}37.88 * * * \\
{[20.95]}\end{array}$ & & & $\begin{array}{l}14.01 * * * \\
{[12.17]}\end{array}$ & & $\begin{array}{l}83.02 * * * \\
{[38.78]}\end{array}$ & \\
\hline GDP Growth & $\begin{array}{l}0.94 * * * \\
{[0.02]}\end{array}$ & $\begin{array}{l}0.94 * * * \\
{[0.02]}\end{array}$ & & & & & & $\begin{array}{l}0.97 \\
{[0.06]}\end{array}$ & \\
\hline Trade Openness & & & & & & $\begin{array}{l}1.04 * * * \\
{[0.01]}\end{array}$ & & $\begin{array}{l}1.03 * * \\
{[0.01]}\end{array}$ & \\
\hline $\begin{array}{l}\text { Democratic Participation } \\
\text { (Polity2 Variable) }\end{array}$ & & $\begin{array}{l}1.61 \\
{[1.19]}\end{array}$ & & & $\begin{array}{l}0.65^{* * *} \\
{[0.10]}\end{array}$ & $\begin{array}{l}1.11^{* * *} \\
{[0.08]}\end{array}$ & $\begin{array}{l}{[5.01 *]} \\
{[4.57]}\end{array}$ & & $\begin{array}{l}1.21 \\
{[0.19]}\end{array}$ \\
\hline Democracy & & & & $\begin{array}{l}0.1 * * * \\
{[0.06]}\end{array}$ & & & $\begin{array}{l}0.07 * \\
{[0.10]}\end{array}$ & & \\
\hline $\begin{array}{l}\text { Autocracy } \\
\text { Democratic Participation }\end{array}$ & & & & & $\begin{array}{l}1.28 * * * \\
{[0.07]}\end{array}$ & & & & \\
\hline (Freedom House Index) & $\begin{array}{l}1.89 \\
{[1.65]}\end{array}$ & & $\begin{array}{l}1.88^{*} \\
{[0.69]}\end{array}$ & $\begin{array}{l}3.46^{* * *} \\
{[1.54]}\end{array}$ & & & & & \\
\hline Political Rights & $\begin{array}{l}0.97 \\
{[0.97]}\end{array}$ & $\begin{array}{l}1.56 \\
{[0.77]}\end{array}$ & & & & & $\begin{array}{l}0.55 \\
{[0.22]}\end{array}$ & & $\begin{array}{l}4.11 * * \\
{[2.58]}\end{array}$ \\
\hline Civil liberties & & & & & $\begin{array}{l}1.01 \\
{[0.31]}\end{array}$ & & $\begin{array}{l}4.07 * * \\
{[2.29]}\end{array}$ & & \\
\hline Executive Constraint & $\begin{array}{l}0.5^{* *} \\
{[0.16]}\end{array}$ & $\begin{array}{l}0.24 \\
{[0.30]}\end{array}$ & $\begin{array}{l}0.51 * * \\
{[0.17]}\end{array}$ & $\begin{array}{l}10.41 * * * \\
{[8.46]}\end{array}$ & & & & & \\
\hline $\begin{array}{l}\text { Political Competition } \\
\text { Restriction of Political }\end{array}$ & $\begin{array}{l}3.4^{* *} \\
{[1.72]}\end{array}$ & $\begin{array}{l}1.92 \\
{[2.13]}\end{array}$ & $\begin{array}{l}3.52 * * * \\
{[1.62]}\end{array}$ & $\begin{array}{l}5.62 * * * \\
{[2.92]}\end{array}$ & & & & & \\
\hline Participation (PERREG) & & & & & & & $\begin{array}{l}2.86 \\
{[6.63]}\end{array}$ & & $0.05 * * *$ \\
\hline $\begin{array}{l}\text { Competitiveness of } \\
\text { Political Participation } \\
\text { (PARCOMP) }\end{array}$ & & & & & & & & & $\begin{array}{l}1.35 \\
{[0.77]}\end{array}$ \\
\hline Regime Durability & & & & & $\begin{array}{l}1.37 * * * \\
{[0.07]}\end{array}$ & $\begin{array}{l}1.19^{*} \\
{[0.11]}\end{array}$ & & & \\
\hline Wald $\chi^{2}($ Prob $>\chi 2)$ & $0.0000^{* * *}$ & $* 0.0000 * * *$ & $0.0000 * * *$ & $0.0000^{* * *}$ & $* 0.0000 * * *$ & $0.0000 * * *$ & $0.0000^{* * *}$ & $0.0000 * * *$ & $=0.0000 * * *$ \\
\hline Log likelihood & -112.165 & -112.359 & -113.815 & -120.947 & -109.265 & -114.575 & -119.719 & -117.368 & -124.961 \\
\hline Constant & -104.201 & -96.236 & -94.246 & -11.679 & 3.181 & -67.217 & 3.373 & -110.328 & 4.016 \\
\hline Observations & 42 & 42 & 42 & 42 & 42 & 43 & 42 & 44 & 42 \\
\hline
\end{tabular}

Note: Results are presented in the form of Incident Rate Ratio's (IRR), Robust standard errors are in brackets; ***,**,* denote significance at 1,5 and $10 \%$ levels. 


\begin{tabular}{|c|c|c|c|c|c|c|c|c|c|}
\hline \multirow{3}{*}{ Dependent Variable } & \multirow{3}{*}{ Model 1} & \multicolumn{8}{|c|}{ Appendix 17: Negative Binomial Estimation Results (robustness check) } \\
\hline & & \multirow[b]{2}{*}{ Model 2} & \multirow[b]{2}{*}{ Model 3} & \multicolumn{4}{|c|}{ (Total Counts of Terrorism Fatalities, 1970-2013) } & \multirow[b]{2}{*}{ Model 8} & \multirow[b]{2}{*}{ Model 9} \\
\hline & & & & Model 4 & Model 5 & Model 6 & Model 7 & & \\
\hline $\begin{array}{l}\text { Tog of GDP } \\
\text { GDP Growth } \\
\text { Trade Openness }\end{array}$ & $\begin{array}{l}11.96 * 4 \\
{[14.17]} \\
0.95 \\
{[0.04]}\end{array}$ & $\begin{array}{c}27.74 * 4 \% \\
{[24.62]} \\
0.95 \\
{[0.04]}\end{array}$ & $\begin{array}{c}37.78 * 4 \% \\
{[32.71]}\end{array}$ & & & $\begin{array}{l}94.54 * * * \\
{[165.36]} \\
1.09 * * *\end{array}$ & & $\begin{array}{c}118.02 * 4 . \\
{[87.43]} \\
0.99 \\
{[0.10]} \\
1.09 * * * \\
{[0.03]}\end{array}$ & \\
\hline $\begin{array}{l}\text { Democratic Participation } \\
\text { (Fresdom House Index) }\end{array}$ & 5.86 & & 1.41 & $2.77 * *$ & & {$[0.03]$} & & & 253 \\
\hline $\begin{array}{l}\text { Political Rights } \\
\text { Civil liberties } \\
\text { Democratic Participation } \\
\text { (P variable) }\end{array}$ & $\begin{array}{l}{[7.92] 034^{-1}} \\
{[0.38]}\end{array}$ & $\begin{array}{l}1.12 \\
{[0.49]} \\
11.36^{* *}\end{array}$ & {$[0.79]^{-1}$} & {$[135]^{-}$} & $\begin{array}{l}0.86 \\
{[0.37]} \\
0.29 * *\end{array}$ & 1 & $\begin{array}{c}0.25 * * \\
{[0.16] 2.57} \\
{[1.78]} \\
35.67 * *\end{array}$ & & $\begin{array}{l}{[2.97]} \\
0.35 \\
{[0.35]}\end{array}$ \\
\hline $\begin{array}{l}\text { Autocracy } \\
\text { Democracy } \\
\text { Executive Constraint } \\
\text { Political Competition } \\
\text { Competitiveness of Political } \\
\text { Participation (PARCOND) }\end{array}$ & $\begin{array}{c}0.1 * * * \\
{[0.06]} \\
23.23 * * \\
{[15.57]} \\
0.37 * *\end{array}$ & $\begin{array}{l}0.4 * \\
{[0.01]} \\
0.94 \\
{[1.27]}\end{array}$ & $\begin{array}{c}0.14 * * * \\
{[0.09]} \\
16.27 * * * \\
{[11.01]}\end{array}$ & $\begin{array}{c}0.04 * * * \\
{[0.03]} \\
11.59 * * \\
{[11.93]} \\
16.84 * * \\
{[9.65]}\end{array}$ & $\begin{array}{l}{[0.08]^{--}} \\
0.07 * * * \\
{[0.03]}\end{array}$ & {$[0.13]^{-}$} & $\begin{array}{l}[42.16]]^{-} \\
{[0.4 *} \\
{[0.00]}\end{array}$ & & $\begin{array}{r}0.52 * * * \\
{[0.09]}\end{array}$ \\
\hline $\begin{array}{l}\text { Restriction of Political } \\
\text { Participation (PERREG) }\end{array}$ & {$[0.17]^{-1}$} & & & & & & 108.53 & & \\
\hline Regime Durability & & & & & $\begin{array}{l}1.33 * * * \\
{[0.10]}\end{array}$ & $\begin{array}{c}1.02 \\
{[0.14]} \\
0.0000 * *\end{array}$ & 0.0000 & & $\begin{array}{c}1.44 \\
{[0.12]^{* * *}} \\
0.00000 *\end{array}$ \\
\hline Wald $/ 2$ (prob>2) & $0,0000 * *$ & $0.0000 * 4 *$ & $0.0000 * * *$ & $0.0000 * * *$ & & & & $0.0000 *$ & \\
\hline $\begin{array}{l}\text { Eoglikelihood } \\
\text { Eonstant }\end{array}$ & $\mid-138951^{-1}$ & $-139024^{-1}$ & -141.695 & $\begin{array}{r}-142363 \\
-11530\end{array}$ & -138.148 & -145846 & $-141^{-} 231^{-}$ & $-149.653^{-1}$ & -138.148 \\
\hline Oonstant & -64619 & -59927 & -92.890 & -11539 & -8.74 & -115509 & $-9.790-$ & -120.655 & $\begin{array}{r}8.714 \\
-42 \\
\end{array}$ \\
\hline
\end{tabular}

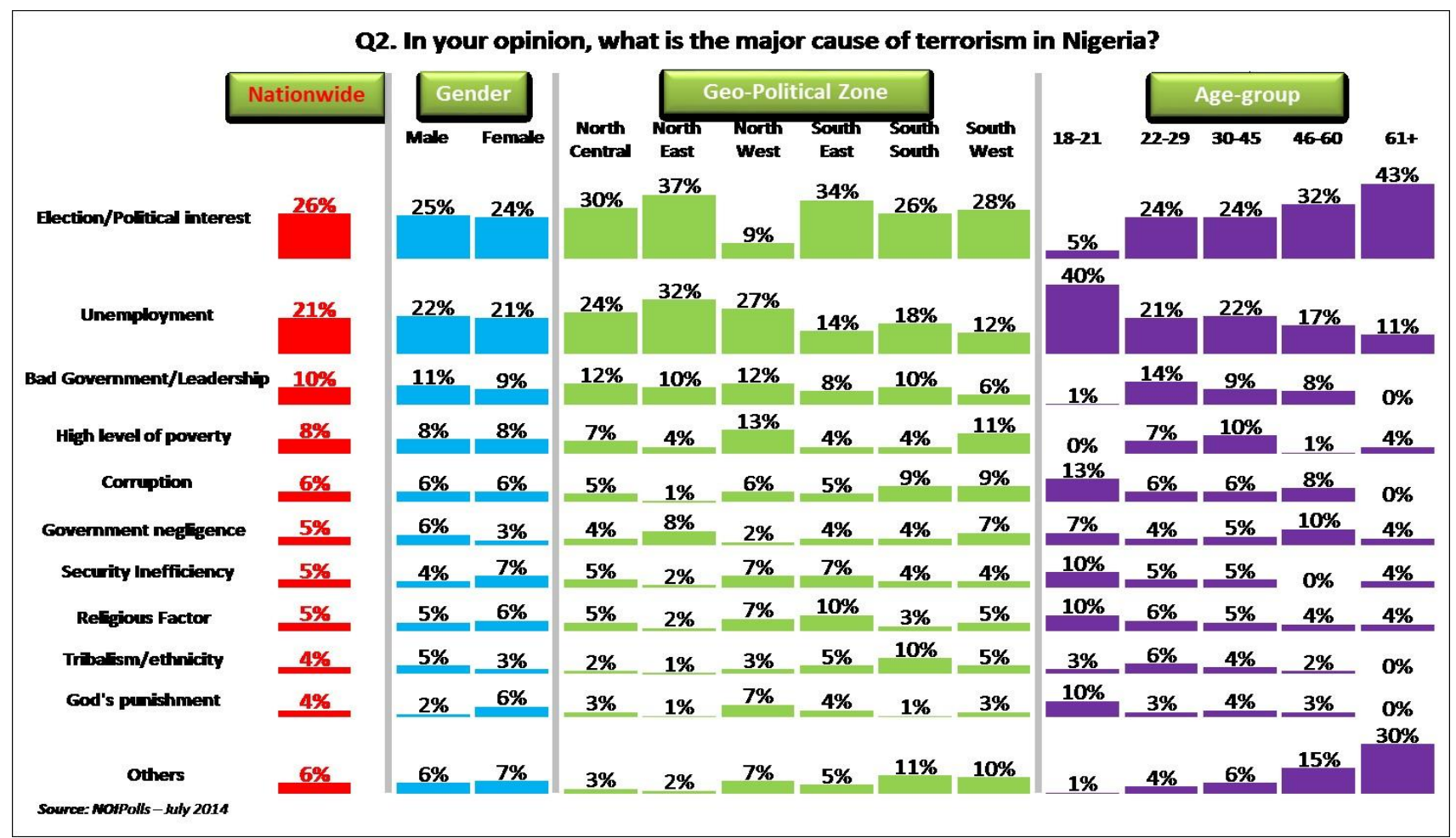

